Meta

Journal des traducteurs

Translators' Journal

\title{
Translating as an Academic and Professional Activity
}

\section{Carmen Valero-Garcés}

Volume 45, numéro 2, juin 2000

URI : https://id.erudit.org/iderudit/004521ar

DOI : https://doi.org/10.7202/004521ar

Aller au sommaire du numéro

Éditeur(s)

Les Presses de l'Université de Montréal

ISSN

0026-0452 (imprimé)

1492-1421 (numérique)

Découvrir la revue

Citer cet article

Valero-Garcés, C. (2000). Translating as an Academic and Professional Activity. Meta, 45(2), 378-383. https://doi.org/10.7202/004521ar

\section{Résumé de l'article}

Cet article étudie le développement de la traductologie en Espagne au cours des deux dernières décennies. Je verrai d'abord quelques-unes des raisons de cet intérêt accru pour la traduction au niveau universitaire, puis j'analyserai l'accroissement de la quantité de publications de travaux académiques portant sur la traduction. Enfin, après avoir discuté de la production d'oeuvres traduites, j'étudierai les relations qu'entretiennent probablement l'édition d'ouvrages portant sur la traduction et celle d'oeuvres traduites. Nous terminerons avec quelques conclusions à propos de l'essor actuel de la traductologie et de la traduction académique.
Ce document est protégé par la loi sur le droit d'auteur. L’utilisation des services d’Érudit (y compris la reproduction) est assujettie à sa politique d'utilisation que vous pouvez consulter en ligne.

https://apropos.erudit.org/fr/usagers/politique-dutilisation/ 


\section{BLOC-NOTES}

\section{Translating as an Academic and Professional Activity}

\section{RÉSUMÉ}

Cet article étudie le développement de la traductologie en Espagne au cours des deux dernières décennies. Je verrai d'abord quelques-unes des raisons de cet intérêt accru pour la traduction au niveau universitaire, puis j'analyserai l'accroissement de la quantité de publications de travaux académiques portant sur la traduction. Enfin, après avoir discuté de la production d'œuvres traduites, j'étudierai les relations qu'entretiennent probablement l'édition d'ouvrages portant sur la traduction et celle d'œuvres traduites. Nous terminerons avec quelques conclusions à propos de l'essor actuel de la traductologie et de la traduction académique.

\section{ABSTRACT}

This paper examines the development of Translation Studies in Spain in the last two decades. I will first explore some reasons for the growing interest in translation at the academic level. Second, I will study the increase in the publishing of academic works on translation. Third, I will comment on the production of translated works, and finally I will explore the possible connections between these two activities- publishing on translation and publication of translated works. This will lead us to some conclusions about the current boom in translation studies and academic translation.

\section{MOTS-CLÉS/KEYWORDS}

translation studies in Spain (1980-2000), publishing of academic works, publishing of translated works, translation at the academic level

\section{INTRODUCTION}

Translating has always been a necessary activity in Western culture. Nevertheless, it is only after the Second World War that translation started to be considered as a professional activity and it was not until the beginning of the 1980s that translating became an independent area of study, thanks to Holmes (1979/1998) and his influential book Translated! Papers on Literary Translation and Translation Studies.

In Spain, this interest in translation as an area of study developed in the mid 1980s. Since then there have been a growing number of academic publications relating to translation topics, and even the creation of a degree in Translation and Interpreting Studies in some Spanish universities. In the following pages, firstly I will show this progressive increase in the publishing of academic works on translation. Secondly, I will comment on the production of translated works, and finally I will explore the possible connections between these two activities - publishing on translation and publication of translated works. This will lead us to some conclusions about the current boom in translation studies and academic translation.

\section{TRANSLATION AS AN ACADEMIC ACTIVITY}

In 1987, J. C. Santoyo published the work Traducción, Traducciones, Traductores (Translating, Translations, Translators), the first bibliography of studies on translation produced in Spain. His work was limited to studies of translations published in Spain or Latin America. In this regard, the author explains that his decision to undertake this task came about because of the non-existence of titles in Spanish in the international bibliographies available. Twelve years later the situation has changed considerably. Some of the reasons for this change - which, I must say, represent a general tendency - are:

1. The intensification of international relationships and cultural exchanges;

2. The consolidation of Translation Studies (TS) as an independent area of study;

3. The increasing specialization of translation (e.g. scientific-technical, legal, economic, etc.);

4. The exploration of new areas of interest in translation (e.g. automatic translation, dubbing, subtitling, oral interpreting, etc.);

5. The professionalization of the activity of translating;

6. Interest in training translators at the university level;

7. The increasing number of conferences and publications directly dealing with TS.

In Spain, since 1987, other bibliographies on translation have been published. I can mention Bibliografía de la traducción en español, catalán, gallego y vasco (A Bibliography on Translation on Spanish, Catalan, Galego and Basque) by J. C. Santoyo (ed.) published in 1996; Manual de bibliografía española de traducción e interpretación: Diez años de historia (1985-1995) (A Spanish Bibliography on Translation and Interpreting: Ten years of History (1985-1995) by F. Navarro Domínguez, also published in 1996, or Análisis de fuentes de 


\begin{tabular}{|c|c|c|}
\hline \multirow{3}{*}{$\begin{array}{l}\text { TRANSLATION STUDIES } \\
\text { AS A DISCIPLINE }\end{array}$} & THEORETICAL STUDIES & $\begin{array}{l}\text { Theory of translation } \\
\text { Studies on the process of translation } \\
\text { Interlinguistic Studies } \\
\text { Terminology }\end{array}$ \\
\hline & DESCRIPTIVE STUDIES & $\begin{array}{l}\text { Literary Translation } \\
\text { History of Translation } \\
\text { Scientific-Technical Translation } \\
\text { Legal Translation } \\
\text { Audiovisual translation }\end{array}$ \\
\hline & APPLIED STUDIES & $\begin{array}{l}\text { Teaching of Translation } \\
\text { Translation in second language teaching } \\
\text { Translation criticism }\end{array}$ \\
\hline
\end{tabular}

información de estudios de traducción. Creación de una base de datos (An Analysis of Sources of Information on Translation Studies: Designing a Database) by R. Palomares, published in 1998 .

These bibliographies, together with some information about recently published books located through their ISBN (information provided by the Ministry of Education and Culture in Spain), are the basis for the present study. However, before presenting the results of my research I would like to explain briefly my classification system for the titles on TS. The classification is mainly based on the original proposal by Holmes (1972/1988: 6780 ), as well as on the study by Hurtado (1994) on the nature of TS, and that by Lvovskaya (1997). lowing:

The resulting classification chart is the fol-

Based on this classification, the following steps will be followed to show the evolution of TS in Spain. First, an analysis will be made of the published books in each of the three main groups that make up TS. For each group, some details and statistical information about the specific subareas will also be provided. Second, an analysis will be made of the translated works, including information about the types of texts translated and the languages involved. Finally, some conclusions will be offered.

Before giving any numbers, it is important to emphasize some changes that have taken place in Spain over the last thirteen years. As we already mentioned, the first Spanish bibliography on translation was published in 1987. On this occasion, its author, J. C. Santoyo, complained about the lack of Spanish authors and titles on the international landscape. Just ten years later, in 1996, he talked about aires totalmente nuevos ("fresh new winds"), and in 1999 we really can speak of a healthy growth of TS in Spain, where more than a dozen different Universities offer a Bachelor's Degree in Translation and Interpreting, some others offer a Master's Degree in Translation and Inter- preting, and some also offer postgraduate studies. These new departments and universities have also quickly incorporated new technology and web resources in the teaching and practice of translation, thus contributing to the creation of a new generation of translators.

Thus, in just a decade publishing about TS has changed in Spain from just a few titles and authors such as García Yebra (1982), Vázquez Ayora (1977) and Santoyo (1983/1985) in the 1980 s to hundreds of titles in the 1990s.

The number of specialised publications on translation has also increased rapidly. I could mention Sendebar (Granada), Livius (León), Vasos Comunicantes (Madrid), Hermes (Sevilla), Hyeronimus Complutensis (Madrid), Viceversa (Vigo), Gaceta de la traducción (Madrid) and TRANS, Revista de traductología (Málaga), as well as Bulletins and Newsletters like BET (Boletín de estudios de traducción), Boletin de APETI. There has also been a rise in the number of conferences, workshops, seminars and meetings all around the country. The proceedings of most of them are usually published, the articles being one of the main sources for TS.

Coming back to publication on translation topics, according to the results of my research the total production in the 1980s and 1990s is approximately 3,000 titles. Of these, 400 to 450 titles were published between 1980 and 1984, and the rest in the last fourteen years (1985-1998) (see Appendix Figure 1).

Using the classification mentioned before and all the titles available from 1986 to 1998 , $35.4 \%$ ( 876 entries) of the total production can be included in the first area of the chart, that is, theory of translation; $56.2 \%$ (1405 titles) can be considered descriptive studies, (group II) or 'particular theories', as Lvosvskaya calls them, and 5.24\% (131 titles) can be considered Applied Studies. 


\subsection{Studies on the theory of translation}

Coming back to the chart presented above and considering the first group, THEORETICAL STUDIES, studies on topics related to the theory of translation have the highest percentage (Figure 2 ), followed by interlinguistic studies and studies on terminology, a subarea in which researchers are showing increasing interest. Another subarea of interest is studies on translation techniques or strategies (11\%).

When dealing with the first subarea, that is, theory of translation, four main approaches can be identified to the study of translation. These are:

1. Linguistic approach

2. Philosophical approach

3. Psycholinguistic approach

4. Sociocultural approach

These four approaches also seem to mark stages in the development of TS as an independent area of study.

According to the data available from my research and also considering the study by Palomares (1998) in the 1970s and 1980s, most studies on translation were from a linguistic perspective. Then, a more philosophical approach together with a psycholinguistic perspective provided a new direction for studies on translation. Since the mid 1980s and especially in the 1990s, there is an increasing interest in considering translation from a sociocultural perspective. In the mid 1990s new tendencies such as computational linguistics and corpus linguistics applied to translation have opened new directions for TS.

This evolution can also be seen by tracking the translation into Spanish of the most representative works in TS. Thus, Steiner's (1975) After Babel was translated in 1980; Nida and Taber's (1974) The Theory and Practice of Translation was translated in 1986; Newmark's (1987) Approaches to Translation was translated in 1992; and Hatim and Mason's (1990) Discourse and the Translator was translated in 1995, to name but a few.

\subsection{Descriptive studies}

As for the second area of TS, DESCRIPTIVE STUDIES, analysis of the data available provides the following information (Figure 3): in general, this group of bibliographic entries has the highest percentage. Of the different subareas considered in the TS classification, the two with the highest percentage are studies on literary translation and studies on the history of translation. The first one represents $47 \%$ of the total, and the second represents 23\%. However, since 1992 there has been an increasing interest in studies on translation of technical and scientific texts (10.2\%), as well as on more specific areas such as legal translation (2\%), audiovisual translation (5\%), and automatic translation $(4 \%)$.

As for literary translation, in Navarro's bibliographic work it counts for more than one third of the total, and in Palomares' it makes up more than $50 \%$. As for the topics, there is a tendency to compare and/or analyse the translation(s) of specific literary works, mostly novels, adopting different points of view: e.g. linguistic, textual, the reception of the translated text, the comparison of different translations of the same original, etc.

As for studies on technical/scientific translation, a quick look at the dates of publication shows that the greatest increase has taken place since 1995, and the topics deal mainly with the use and difficulties of translating specialised vocabulary and structures. As a result, some interesting and useful glossaries have been published on specific areas such as agriculture, environmental sciences, computing sciences, and mass media resources.

As for studies on the history of translation, there is an interest in the analysis of the different versions of classic texts as well as the study of a specific author and the translation of his/her works. Another common topic is the comparison of translations produced at different times, mostly of works from the Middle Ages and the Renaissance, with an emphasis on the works of Shakespeare.

One of the reasons for the interest in these two subareas within descriptive studies might be the philological/linguistic background of a large percentage of the authors, who currently teach in departments of Modern Languages or have recently been incorporated into departments of Translation and Interpreting. The research interests of these professionals and teachers contrast with the more pragmatic orientation of the new Departments of Translation, which leads us to speculate that in a few years the tendency will change towards the production of articles dealing with more practical and professional topics.

\subsection{Applied studies}

The number of publications in this subarea has also increased since 1986 , but at a lower rate than those in groups I or II. Areas of interest are:

1. The teaching of translation

2. The use of translation in the teaching of second languages

3. The analysis of errors of translation

4. Translation criticism

Nevertheless, as Hurtado (1995: 65) points out, despite the development of independent degree progams in translation, there has not been a renewed interest in publishing about the teaching of translation as was expected.

Hurtado (1995: 65) points out some reasons: 
1. Some limitations deriving from the linguistic approach of contrastive studies and the use of so-called 'procedures' or 'techniques' of translation as a method for teaching translation.

2. Lack of agreement about the limits of the theory of translation, and the methodology and didactics of translation.

3. Diversity of focuses in the design of coursebooks, manuals, and teaching materials. At this point it can also be mentioned that, according to an informal study on the use of textbooks conducted by Anthony Pym (University of Tarragona, Spain), it seems that coursebooks are not often used for teaching translation. This fact may partially explain this low rate of publishing.

The didactic materials available can be classified according to the following methodological approaches (Hurtado 1994):

1. Books and materials showing the 'heritage' of traditional didactics for language teaching, that is, books containing lists of vocabulary and mostly literary texts to be translated.

2. Books and materials focused on comparative stylistics and the the study of the techniques of translation in the analysis and production of texts.

3 . Books and materials containing a selection of texts with annotated translations.

4. Books and material including a methodological segment together with annotated or commented translations of whole texts or selected items.

5. Books and materials focused on the theory of translation followed by some applications.

6. Task-based materials and coursebooks. This is the most recent approach which has gained the interest of teachers and developers of syllabi and courses on translation and interpreting.

The second subgroup of interest in applied studies refers to the use of translation as a strategy to learn second languages (approximately 6.7\%), an approach that is receiving increased interest nowadays, but which was widely criticised in the 1980s by the followers of the communicative method in the teaching of second/foreign languages.

As for the other subareas, studies are published, but at an even lower rate. However, the general impression is that publication of applied studies on translation will increase in the next three or four years as more graduate students are drawn into the business world.

\section{TRANSLATION AS A PROFESSIONAL ACTIVITY}

The next step in the present research deals with translation as a professional activity. According to data provided by the Spanish Ministry of Education and Culture through the ISBN, $25 \%$ of all works published in Spain are translated materials, with small variations in recent years. The following data give us an approximate idea:

19859,437 books were translated $=27 \%$ of total production

199611,833 books were translated $=23 \%$ of total production

1997 13,661 books were translated $=24 \%$ of total production.

In 1997, there was an increase of $15.5 \%$ in the number of translated books compared to the total of books published in 1996. A further increase took place in 1998.

What is also worth pointing out is the increasing number of translations between the different languages spoken in Spain: Spanish, Catalan, Basque, Gallego and Valenciano, Spanish and Catalan being the ones with the highest rate. Also, in 1997, the percentage of works translated from Spanish was higher than the percentage of works translated from French, the language that had held the second position for a long time.

The most translated languages overall are English, Spanish, French, German and Italian, from highest to lowest. These languages have maintained a steady position over the last five years, both in terms of global production and in terms of the number of titles translated. Of this total production, $2.4 \%$ are multilingual or bilingual books, the languages most often translated being English and Portuguese as well as Spanish. The interest in studying English in Spain - as all around the world - seems to be the reason for the prominence of English in bilingual or multilingual works. In the case of Portuguese this may be due to business and economic relations, mainly with Brazil.

As for the subjects of translation, again according to ISBN data (from the National Statistics Institute), the translation of literary works for the period 1990-1995 represents $57 \%$ of the total of translated books. If we compare this percentage with the number of articles published on literary translation for the same period, we see a correspondence between research and professional practice.

The same tendency in translating literary works followed by scientific books has been maintained during recent years. For 1997, of the total number of translated literary works the highest percentage corresponds to children's literature $(50 \%)$, followed by other types of literary work $(40 \%)$. In the same year, a rise $(16 \%)$ in the translation of literary works appears when compared with the previous year. When considering the type of literary works translated, narrative has the highest percentage.

After literary works, the second position is held by books related to entertainment and leisure 
(35\%), 49\% being translated from English. In this group the translation of comic books holds the first position $(67 \%)$. Books related to pets and gardening follow.

As for technical and scientific books, the two subareas that hold the highest percentage in terms of translation are computer science $(38.6 \%)$ and medicine $(26.6 \%)$. English and French are the most translated languages.

As for social sciences and humanities, philosophy $(44.8 \%)$ and geography and travel $(34.9 \%)$ are the most translated subjects, with the most common source languages being English, Spanish, French and German.

\section{CONCLUSIONS}

In regard to the first major area of this study, publishing on translation, we can conclude that:

1. Publishing on translation in Spain is quite a booming activity.

2. The recent creation of a Bachelor's Degree in Translation and Interpreting, as well as Masters programs and postgraduate studies, has also produced a rise in academic publishing.

3. Considering the three main groups that make up TS as an independent area of study Theory of Translation, Descriptive Studies and Applied Studies - Descriptive Studies is the most stable.

4. For the first group - Theory of Translation - titles of publications reveal that there are four main approaches to the activity of translating, with an emphasis on intercultural and interdisciplinary studies in the last few years.

5. Within Descriptive Studies, there are two main areas of activity: literary translation and the history of translation. The interest in literary translation has remained unchanged for the last few years, but there has been an increasing number of publications in the last five years that show interest in scientific and technical issues.

6. As for Applied Studies, there is a growing interest in the publication of works related to the training of the translator and the teaching of translation, but changes in the traditional concept of methodology and didactics are not sufficiently reflected, and work by the newly trained generation of translators with a four-year degree in translation and interpreting has to be brought into both the academic and commercial markets.

As for the second major area, that is, translation as an activity, $25 \%$ of all published works in this field are translations. Literary translation has the highest percentage, children's literature being the sub-genre that holds the first position. The translation of technical and scientific texts follows, with computing as the most translated scientific subject.
As for the languages involved, English, German and French are the most commonly translated. However, it is worth mentioning that in 1997 and again in 1998 Spanish was the second most translated language, instead of French.

Considering the above data, I can conclude that both activities, research on translation and translation as a professional task, play an important role in Spain at present. This tendency seems likely to continue in the future, also incorporating new approaches in the area of Applied Studies and Descriptive Studies, presumably dealing with technical and scientific research as well as more specialised areas such as dubbing, legal or computing translation, with decreasing interest in literary translation research. However, currently, there seems to be a balance between research and translated works.

\section{Carmen Valero-Garces} University of Alcala, Spain

\section{REFERENCES}

Delisle, Jean (1980): "L'analyse du discours comme méthode de traduction," Cahiers de Traductologie, 2.

García Yebra, A. (1983): En torno a la traducción. Teoría. Crítica. Historia, Madrid, Gredos.

- (1982): Teoría y práctica de la traducción, Madrid, Gredos.

Hatim, B. and I. Mason (1990): Discourse and the Translator, London, Longman.

- (1995): Teoría de la Traducción: Una aproximación al discurso, transl. J. Peña, Barcelona, Ariel.

Holmes, J. (1988): Translated! Papers on Literary Translation and Translation Studies, Amsterdam, Rodopi.

Hurtado, A. (1994): "Perspectivas de los estudios sobre la traducción," Studis sobre la traducció (A. Hurtado, ed.), Castelló, Universitat Jaume I.

— (1995): "La didáctica de la traducción. Evolución y estado actual," III Curso Superior de Traducción: Perspectivas de la traducción inglés/ español (P. Fernández Nistal and J. M. Bravo, eds.), Valladolid, ICE, pp. 49-74.

_- (1995): "La didáctica de la traducción," Le masque et la plume (E. Le BeL, ed.), Sevilla, Universidad de Sevilla, pp. 65-92.

Lvóvskaya, Z. (1997): Problemas actuales de la traducción, Granada, Granada Lingüística.

Navarro Domínguez, F. (1996): Manual de bibliografía española de traducción e interpretación: Diez años de historia (1985-1995), Alicante, Servicio de Publicaciones de la Universidad.

Newmark, Peter (1987/1992): Manual de traducción, transl. V. Moya, Madrid, Ariel. 
NidA, E. and E. TABER (1974/1986): La traducción: teoría y práctica, transl. A. de la Fuente, Madrid, Cristiandad.

Nord, Ch. (1991): Text Analysis in Translation, Amsterdam, Rodopi.

Palomares, R. (1998): Análisis de fuentes de información de estudios de traducción. Creación de una base de datos, Granada, Servicio de Publicaciones de la Universidad.

Reiss, K. (1996): Fundamentos para una teoría funcional de la traducción, transl. Sandra García and Celia Martín, Madrid, Akal.

Santoyo, J. C. (1985/1989): El delito de traducir, León, Publicaciones de la Universidad.

- (1987): Traducción, traducciones, traductores: Ensayo de bibliografía, León, Universidad de León.

Steiner (1975/1980): Después de Babel, transl. Adolfo Castañón, México, Fondo de Cultura Económica.

VÁzquez Ayora, G. (1977): Introducción a la traductología, Washington, Georgetown University Press.

Vinay, Jean-Paul and Jean Darbelnet (1958/77): Stylistique comparée du français et de l'anglais, Paris, Didier.
Figure 3

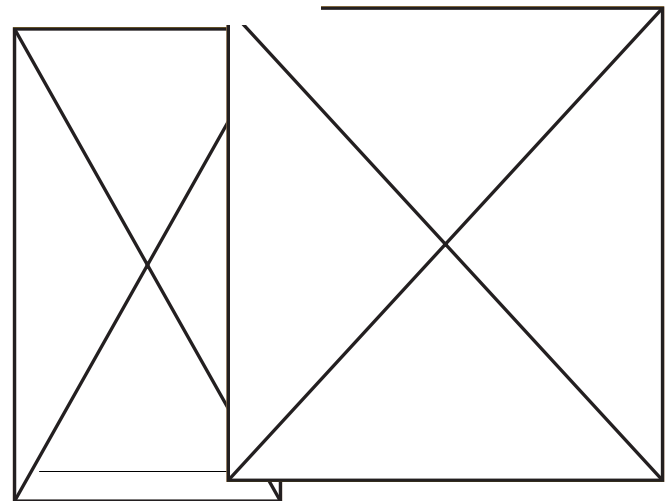
. 